\title{
Discharge and sediment loads of two streams in the mid-hills of central Nepal
}

\author{
Roshan M Bajracharya $\uparrow *$, Subodh Sharma $\uparrow$ and Roberto Clemente \\ † Department of Biological Sciencesand Environmental Science, Kathmandu University, Kavre, Dhulikhel, NEPAL \\ ¥ School of Environment, Resourcesand Devel opment, Asian Instituteof Technology, Bangkok, THAI LAND \\ *Towhom correspondenceshould beaddressed.E-mail:rmbaj@ku.edu.np
}

\begin{abstract}
Stream flow, nutrient loading, and sediment yield closely reflect land use and management practices in relation to growing seasons in mid-hill watersheds of the central Himalaya. A preliminary study was conducted to determine approximate total water discharge and sediment yields from the Galaundi and Pokhare catchments. Mean discharge and sediment loads during the 2002 rainy season were $2.1 \mathrm{~m}^{3} \cdot \mathrm{s}^{-1}$ and $0.9 \mathrm{~kg} \cdot \mathrm{s}^{-1}$ for Galaundi Khola and $0.45 \mathrm{~m}^{3} \cdot \mathrm{s}^{-1}$ and $0.28 \mathrm{~kg} \cdot \mathrm{s}^{-1}$ for Pokhare Khola. Estimates of total annual discharge of water and sediment were, respectively, 27.8 million $\mathrm{m}^{3}$ and $11,400 \mathrm{t}$ (Galaundi) and 6.4 million $\mathrm{m}^{3}$ and 3,500 $\mathrm{t}$ (Pokhare). These corresponded to about $71.6 \%$ and $60.4 \%$ of total rain volumes and soil loss rates of $5.18 \mathrm{t}^{\mathrm{t}} \mathrm{ha} \mathrm{a}^{-1}$ and $5.83 \mathrm{t} \cdot \mathrm{ha} \mathrm{-}^{-1}$ for Galaundi and Pokhare sub-watersheds, respectively. Good correlations were observed for stream discharge vs. sediment concentration $\left(R^{2}=0.83\right.$ and 0.94 respectively) and rainfall amount vs. discharge $\left(R^{2}=0.94\right.$ and 0.96 respectively) for both streams.
\end{abstract}

Key words: stream flow, sediment concentration, land use, pre-monsoon, sub-watershed

Him J Sci 2(3): 51-54, 2004

Available online at: www.himjsci.com
Received: 26 May 2003

Accepted after revision: 1 Mar 2004
Copyright@ 2004 by Himalayan Association for the Advancement of Science (HimAAS)
The mid-hill watersheds of central Nepal are characterized by a myriad of ephemeral and perennial streams, many with steep gradients from source areas to confluence junctions with major rivers. Theseasonal nature of rainfall, being concentrated mostly within the five-month period May to September and steep terrain govern the hydrologic characteristics of thesestreams. Thus, many streams that run dry or dwindle to a meretrickle for much of the year are transformed into raging, torrential streams up to $2 \mathrm{~m}$ deep in some areas. Moreover, land use practices, seasonal paddy cropping, and diversion for irrigation all substantially influence flows and sediment concentration in the streams.

Studies in the watersheds of the Jhikhu Khola (Kavre district) and Yarsha Khola (Dolakha distric) in themid-hills of Nepal have shown that, while major storm events are responsible for generation of thehighestflowsand channel scouringin thesteep mountain streams, the medium-sized events are more likely to be influenced by land cover and land use (Merz et al. 2000). Furthermore, Nakarmi etal. (2000) reported that whilewater storage within those same watersheds was more effective on agricultural than on grazing (grass/shrub) land, erosion was higher at cultivated sites during small to medium rain events. However, in the case of high rainfall events, degraded areas werethemain sources of sediment; the likely mechanism is soil compaction, which causes reduced water infiltration and storage capacity, resulting in high runoff velocities, which lead to gully erosion.

Manystudies indicate that soil erosion, nutrient losses and sediment transport in mountain streamsis greatest on the occasion of those few major storms that typically occur during the pre-monsoon and early growing season (Carver and Nakarmi 1995, Nakarmi et al. 2000, Atreya et al. 2002). The main reasons for this are that during this critical period soil cover is at a minimum and farming operations (tillage, planting, weeding, etc.) are in progress.

TheHimalayan region in general, and themid-hillsof Nepal specifically, are faced with the conflicting needs of a growing human population on the one hand, and, on the other, natural ecosystems urgently in need of protection. This has resulted in escalatingenvironmental degradation dueto unsustainabletimber, fodder, and fuel wood extraction; subsistence agriculture on marginal lands; and infrastructure development. Theseactivities impact the hydrology of mountain watersheds, particularly with regard to flow characteristics and sediment loads, due to soil erosion and changes in water storage and runoff patterns. See I vesand Messerli (1989) aswell asthelves (2004, forthcoming) for a comprehensive assessment of these trends.

Land use changes due to forest clearing; intensification of agriculture (off-season cash crops) and diversion of stream waters for irrigation all impact stream flow, sediment content and nutrient dynamics (Carver and Schreier 1995, Schreier and Shah 2000, Sharma et al. 2002). Therefore, such land use dynamics and farming intensification will requirecareful balancing of water and nutrient budgets for sustainable production and environmental protection (Schreier et al. 1994).

\section{Methods}

Thestreams weresampled periodically (randomly) from January to September 2002, so as to obtain representative data for a range of conditions, from dry season minimum flows to rainy season high flows. Samplings were also performed in conjunction with critical eventssuch aspre-monsoon storms, planting, and harvest, when streams carry unusually high sediment loads.

Datagatheringwasconstrained, however, bytheunfeasibility of sampling during peak flow periods, when river velocities and depthswereprohibitivelyhigh. Also, itwasdifficultto timesampling so as to capture specific rainstorm events of high intensity, especially since these often occurred at night.

Stream velocity was determined using the floatation technique. Cross-sectional areas of each stream weredetermined 
by measuring the depth of water at $0.1 \mathrm{~m}$ intervals across relatively narrow and uniform segments of the streams. Sediment concentration was determined by taking one-liter grab samples from the middle depth of the stream. Water samples were allowed to settle and the residue was then oven-dried to obtain sediment weight per liter of water.

Stream discharge $\left(\mathrm{Q}, \mathrm{m}^{3} \cdot \mathrm{s}^{-1}\right)$ and sediment delivery rate $\left(\mathrm{SDR}, \mathrm{kg} \cdot \mathrm{S}^{-1}\right.$ ) werecalculated according to thefollowing formulas:

$$
\mathrm{Q}=\mathrm{A} * \mathrm{~V} \quad \text { [Eq. 1] }
$$

where,

$A=$ cross-sectional area of stream, $\mathrm{m}^{2}$

$\mathrm{V}=$ flow velocity, $\mathrm{m} \cdot \mathrm{s}^{1}$

$$
\begin{aligned}
& \mathrm{SDR}=\mathrm{Q} * \mathrm{C} \\
& \text { where, } \\
& \mathrm{C}=\text { sediment concentration, } \mathrm{g} \cdot \mathrm{I}^{-1}
\end{aligned}
$$

\section{Results and discussion}

Stream flow measurements indicated that flow volumes in both streams are generally low $\left(<1 \mathrm{~m}^{3} \cdot \mathrm{s}^{-1}\right.$ for Galaundi and $\varangle 0.1 \mathrm{~m}^{3} \cdot \mathrm{s}^{-1}$ for Pokhare). Flow increases dramatically $\left(>4 \mathrm{~m}^{3} \cdot \mathrm{s}^{-1}\right.$ for Galaundi and $>1 \mathrm{~m}^{3} \cdot \mathrm{s}^{-1}$ for Pokhare) shortly after the onset of a major rainstorm, but diminishes rapidly upon cessation of the rainfall. Such quick responses and rapid fluctuations are likely due to the small size of the sub-watersheds and steep stream gradients, as observed by Merz et al. (2000).

Casual examination of the data gathered from random samplings during the rainy season of 2002 (Table1) indicated high variability of both stream flow volumes (discharge) and sediment loads. Simple arithmetic means of the discharge and sediment yield rates during the rainy season were calculated to be about $2.1 \mathrm{~m}^{3} \cdot \mathrm{s}^{-1}$ and $0.9 \mathrm{~kg} \cdot \mathrm{s}^{-1}$ for Galaundi, and $0.45 \mathrm{~m}^{3} \cdot \mathrm{s}^{-1}$ and $0.28 \mathrm{~kg} \cdot \mathrm{s}^{1}$, for Pokhare, respectively. These values are comparableto data from other similar sized sub-watersheds reported in the available literature (Merz et al. 2000). Taking the subwatershed areas to be $22 \mathrm{~km}^{2}$ and $6 \mathrm{~km}^{2}$, we derived crude estimates of mean total water dischargeand sedimentyield duringtherainy season of 25 million $\mathrm{m}^{3}$ and $11,400 \mathrm{t}$ for Galaundi and 5.7 million $\mathrm{m}^{3}$ of water and 3,500 t of sediment for Pokhare, respectively (Table 2).

It was, however, established from both directobservation and inquiry with local residents that for about 7 months duringthedry (October to April) period, stream flows are at a minimum and that sediment load is essentially zero. It was also noted that maximum flowsand sediment loadsoccurred for only a few events, typically in the pre-monsoon and early rainy seasons (May-July) (Table 1). At other times during the rainy season, flows and sediment concentrations were generally low to medium.

Thus, assuming that minimum flows correspond to about $0.16 \mathrm{~m}^{3} \cdot \mathrm{s}^{-1}$ for Galaundi and $0.04 \mathrm{~m}^{3} \cdot \mathrm{s}^{-1}$ for Pokhare, the total dischargevolumesfor thesestreamsduring the remaining ( 7 months) of the year were calculated to be 2.8 million $\mathrm{m}^{3}$ and 0.7 million $\mathrm{m}^{3}$, respectively. Since sediment loads durPokhare Khola ing therest of theyear arenegligible, total sedimentyieldsmay be taken to bethosecalculated for therainy season alone. Summing thetotal water discharge and sediment yield values for rainy and dryseasons for each stream, estimates for the annual mean totals are shown in Table 2 Using the ten-year mean monthly rainfall data of Dhunbesi, Dhading, the total annual flow volumes repre sented $71.6 \%$ and $60.4 \%$ of thetotal rainfall volumesfor Galaundi and Pokhare sub-watersheds, respectively (Table3). The remaining water presumably percolates into the groundwater or is lost through evaporation and transpiration.

Total annual soil removal from the catchments areas, determined by dividing annual sediment yield bythetotal land area of each sub-watershed (approximately 600 ha for Pokhare and 2200 ha for Galaundi), was $5.83 \mathrm{t} \cdot \mathrm{ha}^{-1} \cdot \mathrm{y}^{-1}$ and $5.18 \mathrm{t} \cdot \mathrm{ha}^{-1} \cdot \mathrm{y}^{-1}$ for Pokhare and Galaundi sub-watersheds, respectively. These values fall in the lower range of observed soil loss rates reported in theliterature(Chaliseand Khanal 1997, Nakarmi etal. 2000, UNEP 2001) and reflect the well-managed upland terrace and forested areas over much of the two sub-watersheds. In general, soil erosion appears not to be a major problem in the study sub-watersheds. Thus, adequatemanagementand conservation of agricul-

\begin{tabular}{|c|c|c|c|c|c|c|}
\hline \multirow{2}{*}{$\begin{array}{l}\text { Sampling } \\
\text { Date }\end{array}$} & \multicolumn{3}{|c|}{ Galundi Khola } & \multicolumn{3}{|c|}{ Pokhare Khola } \\
\hline & $\begin{array}{l}\text { Discharge } \\
\left(\mathrm{m}^{3} \cdot \mathrm{s}^{1}\right)\end{array}$ & $\begin{array}{l}\text { Sed. yield } \\
\left(\mathrm{kg} \cdot \mathrm{s}^{1}\right)\end{array}$ & $\begin{array}{l}\text { Sed. conc. } \\
\left(\mathrm{g} \cdot \mathrm{L}^{1}\right)\end{array}$ & $\begin{array}{l}\text { Discharge } \\
\left(\mathrm{m}^{3} \cdot \mathrm{s}^{1}\right)\end{array}$ & $\begin{array}{l}\text { Sed. yield } \\
\left(\mathrm{kg} \cdot \mathrm{s}^{1}\right)\end{array}$ & $\begin{array}{l}\text { Sed. conc. } \\
\left(g \cdot L^{1}\right)\end{array}$ \\
\hline 20/1/02 & 0.17 & 0.00 & 0.00 & 0.03 & 0.00 & 0.00 \\
\hline $26 / 05 / 02^{\dagger}$ & 0.57 & 0.75 & 1.30 & 0.27 & 0.03 & 0.12 \\
\hline $04 / 06 / 02$ & 0.16 & 0.01 & 0.04 & 0.04 & 0.01 & 0.02 \\
\hline $02 / 07 / 02$ & 4.60 & 1.41 & 0.54 & 1.16 & 1.08 & 0.93 \\
\hline $02 / 07 / 02$ & 4.80 & 1.27 & 0.50 & 1.04 & 0.73 & 0.70 \\
\hline $02 / 07 / 02$ & 4.24 & 2.48 & 0.30 & 0.83 & 0.50 & 0.60 \\
\hline $02 / 07 / 02$ & 3.92 & 2.39 & 0.36 & 0.69 & 0.29 & 0.42 \\
\hline $13 / 07 / 02$ & 0.30 & 0.03 & 0.10 & 0.08 & 0.06 & 0.07 \\
\hline $02 / 08 / 02$ & 0.90 & 0.32 & 0.35 & 0.14 & 0.04 & 0.30 \\
\hline $30 / 08 / 02$ & 1.00 & 0.19 & 0.19 & 0.11 & 0.02 & 0.14 \\
\hline $09 / 08 / 02$ & 0.72 & 0.14 & 0.20 & 0.12 & 0.03 & 0.10 \\
\hline Average* & 2.12 & 0.90 & 0.39 & 0.45 & 0.28 & 0.34 \\
\hline
\end{tabular}
tural and forest lands could lead to low overall soil erosion rates (at the catchment scale) and correspondinglylow sediment loads in the streams.

TABLE 1. Stream flows, sediment yields and sediment concentration for Galundi Khola and

$\dagger$ Outlier - excluded from regression analysis

* Average is for rainy season, i.e., May to September, sample size $=10$

TABLE 2. Mean stream water discharge and sediment yield estimates for Galaundi Khola and Pokhare Khola (sample size $=10$ )

\begin{tabular}{lllllllll}
\hline Stream & \multicolumn{2}{c}{ Rainy season } & & \multicolumn{2}{c}{ Dry season } & & \multicolumn{2}{c}{ Total Annual } \\
\cline { 2 - 3 } & $\begin{array}{l}\text { Discharge } \\
\text { volume }\left(\mathrm{m}^{3}\right)\end{array}$ & $\begin{array}{l}\text { Sediment } \\
\text { yield }(\mathrm{t})\end{array}$ & & $\begin{array}{l}\text { Discharge } \\
\text { volume }\left(\mathrm{m}^{3}\right)\end{array}$ & $\begin{array}{l}\text { Sediment } \\
\text { yield }(\mathrm{t})\end{array}$ & & $\begin{array}{l}\text { Discharge } \\
\text { volume }\left(\mathrm{m}^{3}\right)\end{array}$ & $\begin{array}{l}\text { Sediment } \\
\text { yield }(\mathrm{t})\end{array}$ \\
\hline Galaundi & 25 million & 11,400 & & 2.8 million & $\sim 0$ & & 27.8 million & 11,400 \\
\hline Pokhare & 5.7 million & 3,500 & & 0.7 million & $\sim 0$ & & 6.4 million & 3,500 \\
\hline
\end{tabular}


TABLE 3. Mean monthly rainfall, mean total rain volumes and total annual rain volumes and discharge for the two sub-watersheds

\begin{tabular}{|c|c|c|c|}
\hline \multirow[t]{2}{*}{ Month } & \multirow{2}{*}{$\begin{array}{l}\text { Mean rainfall } \\
(\mathrm{mm})\end{array}$} & \multicolumn{2}{|c|}{ Total Rain Volume $\left(\times 10^{3} \mathrm{~m}^{3}\right)$} \\
\hline & & Pokhare & Galaundi \\
\hline January & 18.7 & 112.2 & 411.4 \\
\hline February & 14.2 & 85.2 & 312.4 \\
\hline March & 31.3 & 187.8 & 688.6 \\
\hline April & 39.7 & 238.2 & 873.4 \\
\hline May & 134.9 & 809.4 & 2967.8 \\
\hline June & 309.2 & 1855.2 & 6802.4 \\
\hline July & 418.1 & 2508.6 & 9198.2 \\
\hline August & 492.2 & 2953.2 & 10828.4 \\
\hline September & 228.9 & 1373.4 & 5035.8 \\
\hline October & 48.4 & 290.4 & 1064.8 \\
\hline November & 13.9 & 83.4 & 305.8 \\
\hline December & 16.6 & 99.6 & 365.2 \\
\hline Total Annual Rain & 1766.1 & 10596.6 & 38854.2 \\
\hline \multicolumn{2}{|c|}{ Total Discharge Volume $\left(\mathrm{m}^{3} \cdot \mathrm{s}^{-1}\right)$} & 6400 & 27800 \\
\hline \multicolumn{2}{|c|}{ Percent of discharge to rainfall } & 60.40 & 71.55 \\
\hline
\end{tabular}

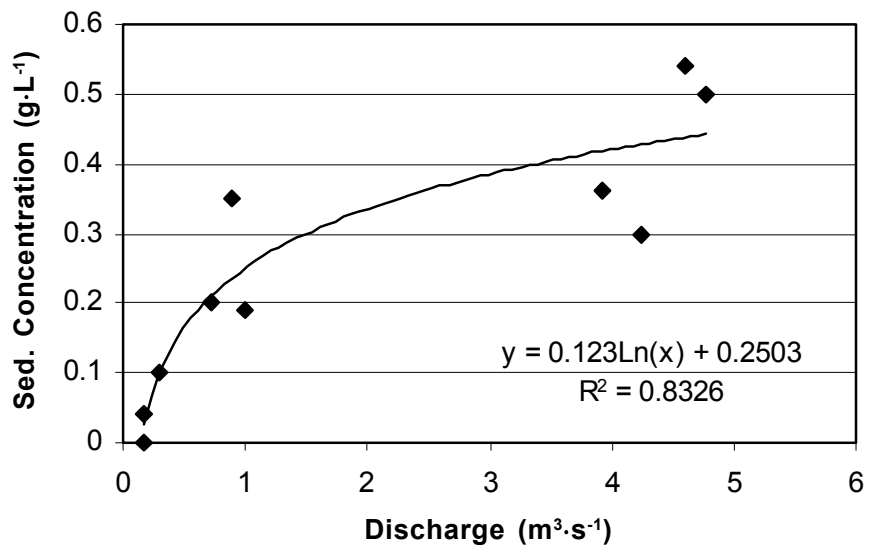

FIGURE 1. Regression plot of flow rate vs. sediment delivery for Galaundi Khola
Regression analyses

Regression plots of sediment concentration versus discharge(Q) for the streams indicated that there were good correlations be tween these parameters for both streams over the range of valuesobtained during the monitoring period. This was reflected in high $R^{2}$ values obtained for the logarithmic and linear regression functions for Galaundi $\left(R^{2}=0.83\right)$ and Pokhare $\left(R^{2}=0.94\right)$, respectively (Figure $\mathbf{1}$ and $\mathbf{2}$ ).

In the case of Galaundi, one outlier eliminated in theanalysis. The relationships for each stream are given by the following equations:

For Galaundi
Sediment Concentration $=0.123 \ln (Q)+0.25 ; R^{2}=0.83$

[Eq. 3]

For Pokhare

Sediment Concentration $=0.696(Q)+0.026 ; R^{2}=0.94$

[Eq. 4]

Nearly $90 \%$ of therainfall occurs during the months of May through September (Figure 3) which corresponds to the period of greatest stream flow, although the sediment concentration in stream water fluctuates greatly, being highest during the early season (May-July) and at sporadic critical periodsthroughout the rainy season, such as paddy planting time (Table 1) and during particularly intense storms, a pattern noted by other researchers (Carver and Nakarmi 1995, Nakarmi etal. 2000, Atreya etal. 2002).

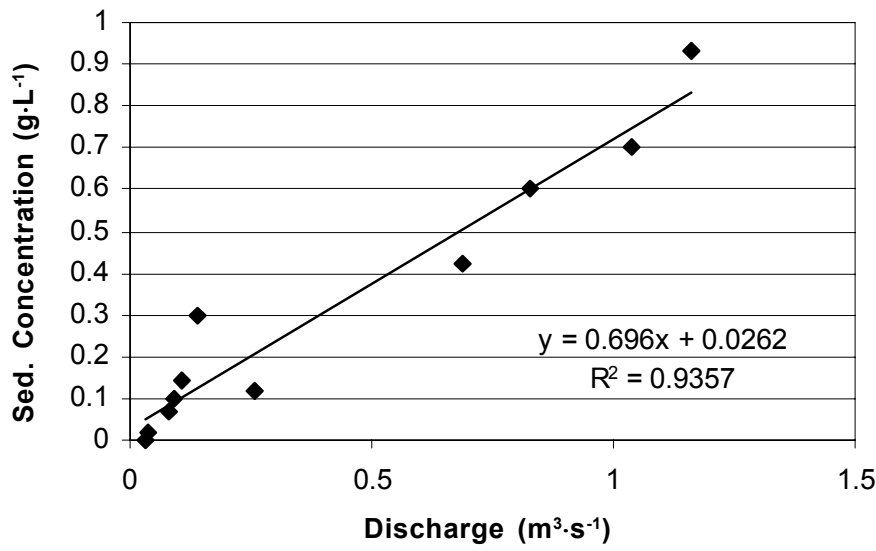

FIGURE 2. Regression plot of flow rate vs. sediment delivery for Pokhare Khola

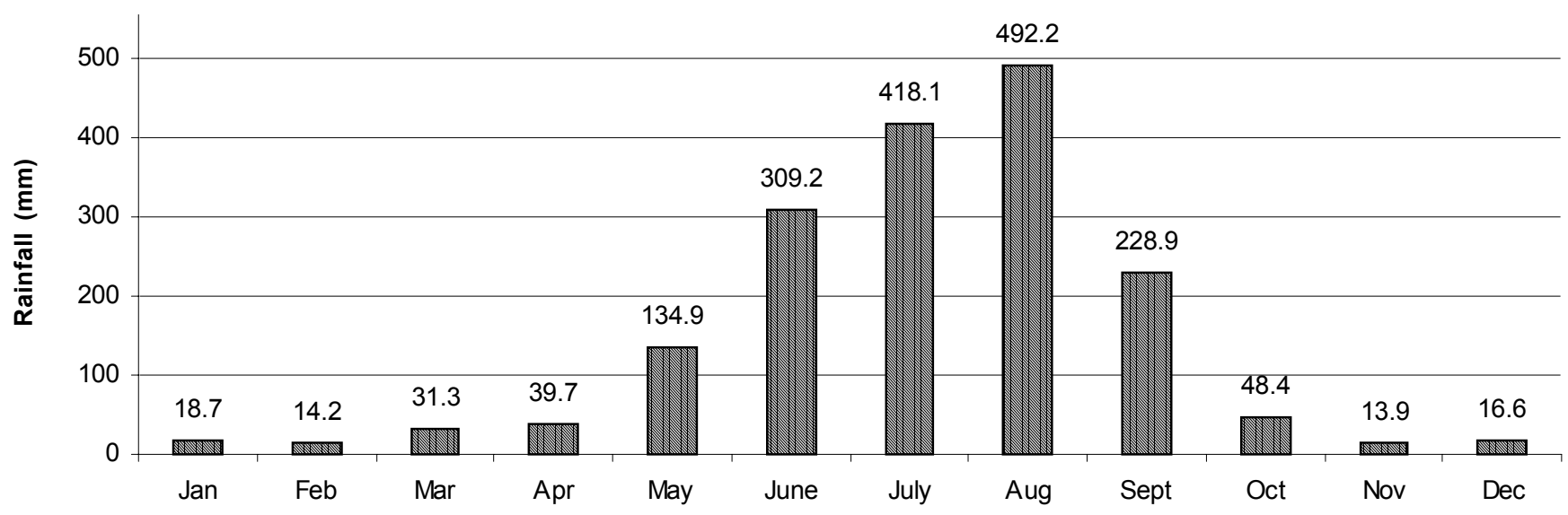

FIGURE 3. Mean monthly precipitation recorded for the study district over a ten-year period from 1991 to 2000 at Dhunbesi Station, Dhading (Source: Department of Hydrology \& Meteorolgy, HMGN 1995, 1997, 1999; Climatological Records from 1987 to 1996) 
Crudecalculations of thetotal volume of precipitation falling over each sub-watershed, based upon the 10-year mean monthly rainfall and total annual stream flow volume as a percent of annual rainfall indicated that abouttwo-thirds of thetotal rainfall flows out of the catchments as stream discharge (Table 3), the rest going to groundwater or evapo-transpiration. Moreover, stream discharge was significantly correlated with rainfall amount for the days monitored ( $24 \mathrm{~h}$ period during which sampling was done) as seen from the regression plots (Figure 4).

For the limited number of observations made, good correlationswereseen between 24-hour rainfall totalsand sameday discharge rates for both streams (Figure 4). This indicated that stream flow responds rapidly to rainfall dueto the small size and steep gradients for both Pokhare and Galaundi subwatersheds. Because of this fact, however, timing of stream dischargemeasurement iscritical and pinpointing peak discharge is difficult.

\section{Conclusions}

Climatic and stream flow data revealed that most of the rainfall occurs from May to September and that during much of this period discharge from both streams is low. High flows tend to occur a few hours after heavy storms due to the steep gradients and small catchment areas of the streams. High sediment concentrations were confined to critical periods such as the premonsoon intense rains and during tillage/ planting times when the soil is least protected and most disturbed. Soil erosion did not appear to bea major problem in thestudy watersheds, presumably due to adequate management and conservation practices on agricultural and forestlands. Despite limited observations, good correlations were obtained for discharge vs. sediment load and rainfall amount vs. discharge for both streams. Land use and farming practices clearly influence the nature of stream flow, as well as sediment loading in streams with steep gradients in the mid-hills. Further workis, however, needed to establish thecausal relationshipsamong land use, agricultural intensification, stream discharge, and soil and nutrient losses, in order to formulate ecologically and economically sound recommendations for sustainableland management.

\section{Acknowledgements}

Funding provided by DANIDA through AIT, Thailand, is gratefully acknowledged. Logistic support extended by Nepal Agroforestry Foundation and Kathmandu Universityishighlyappreciated.

\section{References}

Atreya K, SSharma and RM Bajracharya. 2002. Minimization of soil and nutrient lossesfrom maize-based croppingsystemsin Central Nepal Mid-hills. Paper presented at National Seminar on Biodiversity and Sustainable Use of Bioresources; 2002 Oct 10-12; Department of Limnology, Barkatullah University, Bhopal, India

Carver M and G Nakarmi. 1995. The effect of surface conditions on soil erosion and stream suspended sediments. In: Schreier H, PB Shah and SBrown (eds) Challengesin Mountain resourcemanagement in Nepal: Processes, trends and dynami csin middleMountain watersheds. Kathmandu: International Center for Integrated Mountain Development. p 155-162

Carver M and H Schreier. 1995. Sediment and nutrient budgets over four spatial scalesin the Jhikhu Khola watershed:Implicationsfor land usemanagement In: Schreier H, PB Shah and SBrown (eds), Challengesin Mountain resource management in Nepal: Processes, trendsand dynamicsin middleMountain watersheds. Kathmandu: International Center for Integrated Mountain Development. p 163-170

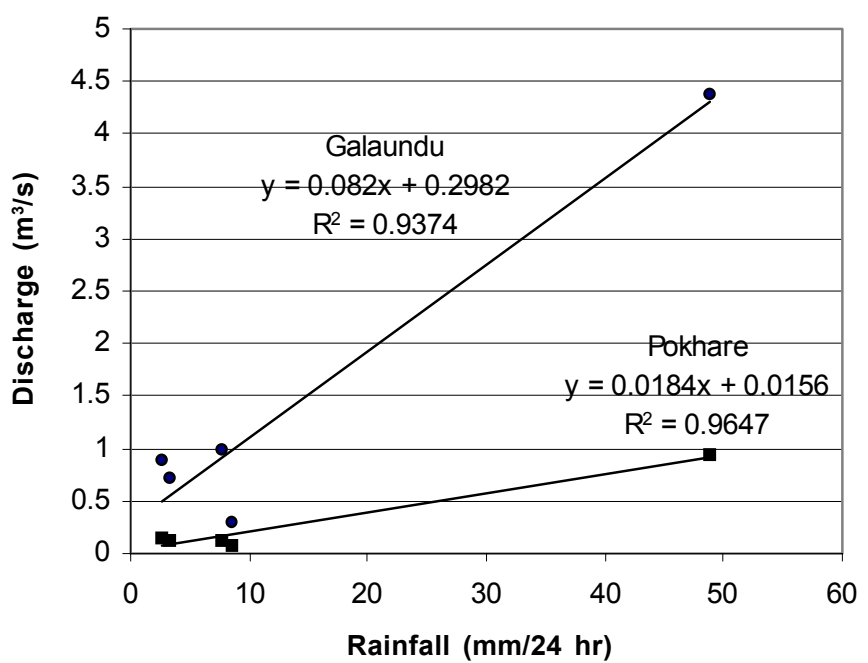

FIGURE 4. Regression plots of $24 \mathrm{~h}$ rainfall amount and stream discharge (flow rate, measured during the $24 \mathrm{~h}$ period)

ChaliseSR and NR Khanal. 1997. Erosion processes and their implication in sustainable management of watersheds in Nepal Himalayas. In: Gustard A, SBlazkova, M Brilly, S Demuth, J Dixon, H van Lanen, C Llasat, S Mkhandi and E Servat (eds), Regional hydrology: Concept and modelsfor sustainable water resource management. Proceedings of the Postojna, Slovenia conference; 1997 Sept-Oct. Wallingford (UK): International Association of Hydrological Science. IAHS publishing no 246. 363p

DHM. 1995. Climatological records of Nepal, 1987-1990. Kathmandu:Department of Hydrology and Meteorology, HMGN

DHM. 1997. Climatological recordsof Nepal, 1991-1994. Kathmandu: Department of Hydrology and Meteorology, HMGN

DHM. 1999. Climatological recordsof Nepal, 1995-1996. Kathmandu: Department of Hydrology and Meteorology, HMGN

Ives JD. 2004 (forthcoming). Himalayan perspectives. London and New York: Routledge

Ives JD and B Messerli. 1989. TheHimalayan dilemma: Reconciling development and conservation. London: Routledge. $295 p$

Merz J, BSDongol, RWeingartner and G Nakarmi. 2000. Impact of land use on generation of high flows in theYarsha khola watershed. In: Allen R, H Schreier, SBrown and PB Shah (eds), Thepeopleand resourcedynamicsproject: The first threeyears (1996-1999). Proceedings of a Workshop held in Baoshan, China; 1999 March 2-5. Kathmandu: International Center for Integrated Mountain Development. p 185-198

Nakarmi G, H Schreier, J Merg and P Mahatma. 2000. Erosion dynamics in the Jhikhu and Yarsha khola watershed in Nepal. In: Allen R, H Schreier, SBrown and PB Shah (eds), Thepeopleand resourcedynamicsproject: Thefirst three years (1996-1999). Proceedings of aWorkshop held in Baoshan, China; 1999 March 2-5. Kathmandu: International Center for Integrated Mountain Development. p 209-218

Schreier H and PB Shah. 2000. Soil fertility status and dynamics in the Jhikhu and Yarsha khola watershed. In: Allen R, H Schreier, SBrown and PB Shah (eds), Thepeopleand resourcedynamicsproject: Thefirst threeyears(1996-1999) Proceedings of a Workshop held in Baoshan, China; 1999 March 2-5. Kathmandu: International Center for Integrated Mountain Development. $p$ 281-9

Schreier H, PB Shah, LM Lavkulich and SBrown. 1994. Maintaining soil fertility under increasing land use pressures in themiddlemountains of Nepal. Soil UseManage 10: 137-42

Sharma S, RM Bajracharya and R Clemente. 2002. Freshwater resources and quality in the Galaundu-Pokhare Khola subwatershed, Dhading, Nepal. Bangkok: School of Environment and ResourceDevelopmet, Asian Institute of Technology. Project Report. p 1-33

UNEP. 2001. Soil degradation. In: Nepal:Stateof theenvironment 2001. Thailand: United Nations Environment Programs. p 79-95 